\title{
PENGOLAHAN CITRA SATELIT ALOS PALSAR MENGGUNAKAN METODE POLARIMETRI UNTUK KLASIFIKASI LAHAN WILAYAH KOTA PADANG
}

\author{
Farah Sarjani $^{1}$, Josaphat Tetuko Sri Sumantyo ${ }^{2}$, Yohandri ${ }^{1}$ \\ ${ }^{1)}$ Jurusan Fisika, FMIPA Universitas Negeri Padang \\ ${ }^{2)}$ Josaphat Microwave and Remote Sensing Laboratory, Chiba University, Japan \\ farah.sarjani@gmail.com,jtetukoss@faculty.chiba-u.jp, yohandri.unp@gmail.com
}

\begin{abstract}
Penelitian ini bertujuan untuk mendeskripsikan proses pengolahan citra satelit Alos PalSAR level 1.1 untuk klasifikasi lahan di Kota Padang. Metode klasifikasi yang digunakan adalah metode full polarimetri yang dapat menerima dan memproses semua kombinasi dari empat polarisasi $\mathrm{HH}, \mathrm{HV}, \mathrm{VH}$, dan VV. Hasil penelitian menunjukkan pada metode polarimetri Yamaguchi Decomposition diperoleh empat klasifkasi objek dengan modifikasi penyederhanaan kelas yaitu warna biru untuk surface scattering yang umumnya menggambarkan tentang perairan di permukaan bumi, warna hijau untuk volumetric scattering yang menggambarkan tentang tumbuh-tumbuhan, hutan dan sejenisnya, merah atau pink untuk double bounce scattering yang menggambarkan tentang pemukiman, perkotaan, bangunan dan sejenisnya dan kuning untuk helix scattering dimana sama halnya seperti double bounce namun helix akan lebih jelas mengidentifikasi pemukiman yang tertutupi tumbuhan.
\end{abstract}

Keywords : Polarimetri, Alos PalSAR, Yamaguchi Decomposition, Scattering

\section{PENDAHULUAN}

Indonesia telah memanfaatkan citra penginderaan jauh, berbasis citra optik untuk melakukan klasifikasi lahan. Wilayah Indonesia yang berada pada daerah tropis menjadi salah satu kendala dalam menggunakan data citra optik. Indonesia memiliki dua musim tiap tahunnya, yaitu musim hujan dan musim kemarau. Pada musim hujan, awan menjadi kendala dalam menggunakan data citra optik. Sedangkan pada musim kemarau, yang menjadi kendala adalah asap yang disebabkan oleh kebakaran hutan dan lahan. Adanya awan dan asap sangat mengganggu dalam proses identifikasi dan pemantauan obyek di permukaan bumi, hal ini seringkali membuat informasi terbaru di bawah awan atau asap tidak tersedia. Untuk mengatasi kelemahan dari citra optik maka saat ini telah tersedia suatu sistem penginderaan jauh aktif berbasis radar.

Kota Padang menjadi parameter kemajuan kota-kota lain di Provinsi Sumatera Barat. Penggunaan lahan di Kota Padang dari tahun ketahun mengalami perubahan yang mengarah dari pertanian menjadi non pertanian karena bertambahnya penduduk yang mengakibatkan berkembangnya pemukiman-pemukiman penduduk. Selain itu, wilayah Kota Padang yang sering dilanda banjir mengakibatkan wilayah Kota Padang cepat berubah. 
Ketersediaan data yang akurat mengenai per- kembangan lahan sangat penting untuk dijadikan sebagai dasar dalam pengambilan keputusan. Salah satu sarana untuk menyediakan data klasifikasi lahan adalah dengan memanfaatkan teknologi penginderaan jarak jauh.

Penginderaan jauh adalah ilmu dan seni untuk memperoleh informasi tentang suatu obyek, daerah, atau fenomena melalui analisis data yang diperoleh dengan alat tertentu tanpa kontak langsung dengan obyek, daerah, atau fenomena yang dikaji ${ }^{[1]}$. Penginderaan jauh sebagai sumber data spasial memberikan kemudahan baik dari segi waktu, tenaga, dan biaya bagi penggunanya. Apalagi jika data yang dibutuhkan mencakup wilayah yang luas, penginderaan jauh menjadi alternatif pilihan terbaik untuk penyediaan data. Saat ini teknologi penginderaan jauh sudah berkembang pesat dan banyak digunakan oleh pemerintah, peneliti, kalangan akademik, sampai komersil. Dengan menggunakan satelit, maka memungkinkan untuk memonitor daerah yang sulit dijangkau dengan metode dan wahana yang lain.

Satelit dengan orbit tertentu dapat memonitor seluruh permukaan bumi. Satelit-satelit yang digunakan dalam penginderaan jauh terdiri dari satelit lingkungan, cuaca, dan sumber daya alam. Sensor penginderaan jauh akan menangkap gelombang pantulan balik dari obyek dan merekam nilai intensitas gelombang balik tersebut. Sistem sensor adalah sistem rangkaian yang digunakan dalam pemanfaatan gelombang elektromagnetik pantul dan pancar dalam memperoleh data/informasi suatu objek ${ }^{[2]}$. Secara umum, sistem sensor penginderaan jauh dibagi dalam dua tipe, yaitu Penginderaan jauh sensor aktif dan Penginderaan jauh sensor pasif.
E-ISSN : 2549-7464, P-ISSN : 1411-3724

Penginderaan jauh sensor aktif adalah sistem penginderaan jauh yang memanfaatkan gelombang yang ditransmisikan oleh sensor yang kemudian ditangkap kembali oleh sensor setelah dipantulkan oleh obyek di permukaan bumi. Citra dengan sistem penginderaan jauh sensor aktif diantaranya adalah ALOS PALSAR (Advanced Land Observing Satellite Phased Array type L-band Synthetic Aperture Radar), ERS (Earth Resource Satellite), dan citra RADAR SAT (Radio Detection And Ranging Satelit). Penginderaan jauh sensor pasif merupakan sistem penginderaan jauh yang merekam pantulan gelombang dengan sumber energi yang berasal dari matahari atau obyek itu sendiri. Citra dari hasil penginderaan jauh dengan sensor pasif diantaranya adalah Landsat (Land Satellite), QUICK BIRD, dan SPOT (Sisteme Probatoire d'Observation de la Terre $)^{[2]}$.

Radar merupakan singkatan dari Radio Detection And Ranging. Radar termasuk penginderaan jauh gelombang mikro aktif, yaitu penginderaan jauh dimana sensornya menyediakan energi atau cahayanya sendiri. Radar merupakan alat yang menggunakan gelombang radio untuk mendeteksi keberadaan serta menentukan posisi suatu obyek ${ }^{[1]}$. Proses yang termasuk di dalamnya antara lain mengirimkan pulsa energi gelombang mikro pada obyek yang diinginkan dan merekam kekuatan dan asal pantulan yang diterima oleh obyek di dalam area pencitraan. Sistem radar mempunyai tiga fungsi utama, yaitu: (1) mengirim sinyal gelombang mikro ke suatu obyek/ target, (2) menerima energi transmisi hamburan balik dari obyek/ target, (3) mengamati kekuatan/ energi (deteksi) dan waktu jeda (ranging) dari sinyal balik. Radar yang bersifat imaging disebut juga Synthetic Aperture Radar (SAR). Synthetic Aperture Radar (SAR) merupakan sistem radar koheren yang membentuk citra penginderaan jauh resolusi tinggi yang dapat digunakan pada siang maupun malam hari. SAR dapat 
digunakan pada siang maupun malam hari pada segala jenis kondisi cuaca, hal ini dikarenakan sistem SAR menggunakan gelombang radio (microwave) untuk pengamatan permukaan bumi. Proses yang ada di dalamnya antara lain mengirimkan pulsa energi gelombang mikro pada obyek yang diinginkan dan merekam kekuatan asal pantulan yang diterima oleh obyek di dalam area pencitraan. Kelebihan-kelebihan radar antara lain bebas dari gangguan yang terjadi di atmosfer, seperti awan, asap dan hujan dan dapat mencitra pada siang hari maupun malam hari.

Parameter sistem radar terdiri dari: 1) polarisasi, yaitu orientasi medan elektrik dan magnetik gelombang elektromagnetik. Sistem radar dapat disusun untuk mengirim dan menerima radiasi elektromagnetik baik secara horizontal maupun vertical. 2) frekuensi, Frekuensi radar menentukan kedalaman penetrasi gelombang untuk target yang diindera dan kekasaran relatif permukaan. 3) resolusi, adalah ukuran suatu kemampuan sistem untuk membedakan bentuk individual pada suatu scene. SAR mempunyai dua dimensi pada resolusi sensornya, yaitu resolusi jangkauan (range) dan resolusi azimut. Resolusi jangkauan ditentukan oleh sistem dan prosesor pada radar yang berpengaruh pada jangkauan miring (slant range). Resolusi jangkauan dipengaruhi oleh panjang pulsa. Resolusi azimut ditentukan oleh lebar beam angular dari bidang permukaan bumi yang terindera oleh beam radar. Untuk dua obyek yang terpisah maka kedua obyek tersebut harus dipisahkan pada arah azimut dengan jarak yang lebih besar dari pada lebar beam di permukaan bumi. 4) Geometri citra radar, Prosesor SAR diharuskan membuat konversi geometrik yang dibutuhkan dari slant range ke ground range. Parameter utama untuk konversi slant range ke ground range adalah sudut jatuh (incidence angle). Sudut jatuh merupakan sudut antara cahaya iluminasi radar dan permukaan bumi. Sudut jatuh tergantung dari tinggi satelit radar dari
E-ISSN : 2549-7464, P-ISSN : 1411-3724

permukaan bumi. Sudut ini akan berubah dari near range ke far range dimana perubahan ini akan mempengaruhi geometri citra radar. Sudut jatuh ini ditentukan oleh sistem radar itu sendiri dan sudut jatuh lokal.

Citra (image atau scene) merupakan representasi dua dimensi dari suatu objek di dunia nyata. Khusus pada bidang remote sensing (dan pengolahan citra digital), citra merupakan gambaran sebagian permukaan bumi sebagaimana terlihat dari ruang angkasa (satelit) atau dari udara (pesawat terbang). Citra ini dapat diimplementasi-kan ke dalam dua bentuk umum: analog atau digital. Foto udara atau peta foto (hardcopy) adalah salah satu bentuk dari citra analog, sementara citracitra satelit yang merupakan data hasil rekaman sistem sensor- sensor (radar, detector, radiometer, scanner, dan lain jenisnya) hampir semuanya merupakan bentuk citra digital ${ }^{[3]}$. Klasifikasi citra merupakan proses pengelompokan pixel pada suatu citra ke dalam sejumlah kelas (class) sehingga setiap kelas dapat menggambarkan suatu identitas dengan ciri-ciri tertentu. Tujuan utama klasifikasi citra penginderaan jauh adalah untuk menghasilkan peta tematik, dimana suatu warna mewakili suatu objek tertentu. Contoh objek yang berkaitan dengan permukaan bumi antara lain air, hutan, sawah, kota, jalan, dan lain- lain. Sedangkan pada citra satelit meteorologi, proses klasifikasi dapat menghasilkan peta awan yang memperlihatkan distribusi awan di atas suatu wilayah ${ }^{[4]}$.

Salah satu satelit yang membawa sensor radar adalah satelit ALOS (Advanced Land Observing Satellite). ALOS adalah satelit penginderaan jauh milik Jepang yang merupakan satelit generasi lanjutan dari JERS-1 (Japanese Earth Resources Satellite-1) dan ADEOS (Advanced Earth Observing Satellite). Satelit ALOS diluncurkan pada tanggal 24 Januari 2006 
dengan menggunakan roket H-IIA milik Jepang dari stasiun peluncuran Tanegasima Spaca Center, Jepang bagian selatan (JAXA, 2013) dengan membawa tiga jenis sensor, yaitu PRISM (Panchromatik Remotesensing Instrument for Stereo Mapping), AVNIR-2 (Advanced Visible and Near Infrared Radiometer type-2), PALSAR (Phased Array type L-band Synthetic Apeture Radar). Periode orbit satelit untuk kembali pada satu titik tertentu adalah 46 hari dengan ketinggian orbit $691 \mathrm{~km}^{[5]}$.

Citra ALOS PALSAR merupakan citra radar yang diperoleh dari hasil perekaman pantulan balik gelombang mikro oleh objek. Data citra ALOS PALSAR berisikan kenampakan tingkatan karakteristik backscatter dari obyek di permukaan bumi ${ }^{[2]}$. Kelebihan dari citra ini adalah hasil dari perekaman citra tersebut tidak dipengaruhi oleh waktu perekaman baik siang ataupun malam serta kondisi cuaca atmosfer bumi (kabut dan awan). Produk standar ALOS PALSAR terdiri dari beberapa level. Level 1.0 merupakan tipe data citra radar yang merupakan data yang belum dalam format SLC (single look complex). SLC merupakan tipe data citra radar yang merupakan kompresi dari raw data terhadap matriks karakteristik backscater. Pada level 1.0, susunan data sinyal belum dipadatkan dan dilengkapi dengan koefisien kalibrasi radiometrik dan koreksi geometrik dalam model polimetri dengan data polarimetri yang dipisahkan. Level 1.1 merupakan data yang sudah dikalibrasi secara radiometrik pada masukan sensor serta sudah dalam format SLC. Citra ALOS PALSAR level 1.1 yang digunakan dalam penelitian ini merupakan citra radar dengan tipe full polarimetry. Data radar tipe ini terdiri dari empat saluran dengan karakteristik polarisasi tipe $\mathrm{HH}, \mathrm{HV}$, VVdan VH. Dengan memanfaatkan empat saluran yang dimiliki citra ALOS PALSAR maka dapat dibentuk citra yang dapat digunakan dalam proses pengklasifikasian citra radar. Dalam pemrosesan sebuah citra radar tidak
E-ISSN : 2549-7464, P-ISSN : 1411-3724

terlepas dari adanya efek noise speckle, maka perlu ditentukan jenis filter yang tepat untuk mereduksi noise speckle tersebut agar mempermudah proses klasifikasi citra digital.

\section{METODE PENELITIAN}

Penelitian data satelit ALOS PALSAR ini dilakukan dengan proses pengolahan citra digital dengan menggunakan perangkat komputer. Pemrosesan dilakukan dengan bantuan perangkat lunak SNAP menggunakan metode polarimetri dan data yang digunakan diperoleh dari JMRSL Chiba university dengan level 1.1. Data ini sudah dikalibrasi secara radiometrik pada masukan sensor yang sudah dalam format SLC (Single Look Complex). Data penelitian diperoleh dengan menggunakan metode full polarimetri, dimana teknik ini menggunakan empat fine sekaligus yaitu, $\mathrm{HH}, \mathrm{HV}, \mathrm{VV}$ dan $\mathrm{VH}$ karena polarimetri merupakan kombinasi antara transmitter dan receiver yang menjelaskan perbedaan penggunaan polarisasi pada sebuah pengolahan citra. Radar polarimetri ini dapat mengirim dan menerima polarisasi horisontal dan vertikal. Dengan demikian, mereka dapat menerima dan memproses semua kombinasi dari empat polarisasi $\mathrm{HH}, \mathrm{HV}, \mathrm{VH}$, dan VV. Data yang diolah adalah daerah kota Padang yang direkam pada 7 Juni 2010.

Pengolahan citra Alos PALSAR mengguna-kan metode polarimetri meliputi beberapa tahapan yaitu:creating subset, Radiometric calibration, Matrix generation, Speckle filtering, dan Decomposition. Pada umumnya, koreksi radiometri mem- pertimbangkan faktor gangguan atmosfer sebagai sumber kesalahan utama. Efek atmosfer menyebabkan nilai pantulan obyek di permukaan bumi yang terekam oleh sensor menjadi bukan merupakan nilai aslinya, tetapi menjadi lebih besar oleh karena 
adanya hamburan atau lebih kecil karena proses serapan. Citra yang perlu dikoreksi radiometrik pada umumnya nilai digital number terendahnya melebihi nol. Nilai lebih tersebut dihitung sebagai nilai offset dan nilai tersebut merupakan besarnya pengaruh gangguan atmosfer ${ }^{[6]}$. Pada tahap polarimetri matrix generation bisa menggunakan kovarians matrik C2,C3,C4 dan koherensi matrik T3 dan T4. Pada prosedur ini band yang dikonver adalah matrix T3 karena elemen-elemen yang terdapat pada T3 mempunyai interpretasi fisik yang lebih baik dan matrix ini lebih sering digunakan.

Salah satu karakteristik citra SAR adalah timbulnya noise speckle, yang tampak sebagai tekstur bintik-bintik teranggelap yang terdistribusi secara random dalam citra. Noise tersebut timbul akibat interferensi konstruktif dan destruktif diantara sinyal-sinyal hamburan balik dari berbagai obyek secara random dalam suatu area tertentu yang disinarinya ${ }^{[7]}$.

Terdapat 4 parameter yaitu Box car Filter, Idan Filter, Refined Lee Filter dan Lee Sigma Filter. Salah satu cara untuk menghilangkan noise melalu speckle filtering yaitu dengan memilih polarimetri speckle filter dari menu polarimetri. Decomposition berfungsi untuk memisahkan kontribusi hamburan untuk setiap informasi. Ada banyak parameter yang tersedia pada bagian decomposition ini namun yang paling banyak digunakan adalah Yamaguchi Decomposition. Yamaguchi decomposition dapat menghasilkan empat tipe scattering. Terdapat area pada image SAR dimana kondisi refleksi simetri tidak terekam. Yamaguchi dkk pada tahun 2005, mengusulkan empat komponen model scattering. Komponen keempat yang diperkenalkan adalah helix scattering. Istilah Helix scattering ini muncul untuk daerahdaerah yang heterogen (struktur buatan manusia) dimana menghilang (tidak terekam) ketika terjadi hamburan distribusi
E-ISSN : 2549-7464, P-ISSN : 1411-3724

alami. Yamaguchi dekomposisi memliki empat model mekanisme scattering yaitu: helix, double bounce, surface scattering, volume scattering ${ }^{[8]}$.

\section{HASIL PENELITIAN DAN PEMBAHASAN}

\section{Hasil Penelitian}

Data yang diperoleh dalam penelitian yang telah dilakukan adalah data pengolahan citra menggunakan metode full polarimetri. Untuk hasil setiap pengolahan mengalami perubahan yang dapat dilihat pada tahap-tahap polarimetri yang digunakan. Pada tahap create the subset, citra dipotong sesuai dengan koordinat daerah yang dibutuhkan. Citra yang diolah yaitu wilayah kota Padang pada tanggal 7 Juni 2010 yang dapat dilihat pada Gambar 1.

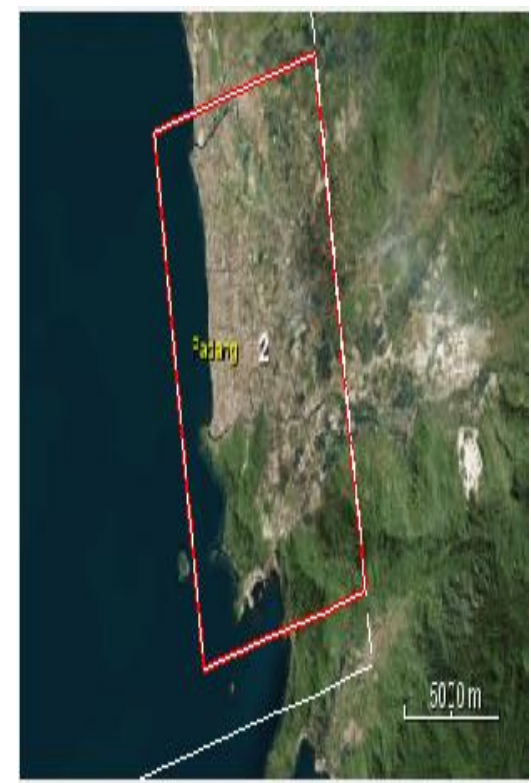

\section{Gambar 1. Daerah Perekaman Citra} Alos Palsar

Untuk melihat produk citra Alos PALSAR pilih salah satu dari 4 pilihan band yang tersedia $(\mathrm{VH}, \mathrm{VV}, \mathrm{HH}, \mathrm{HV})$ misalnya intensitas $\mathrm{VH}$ band seperti yang terlihat pada Gambar 2.

Setelah produk citra muncul, tahap selanjutnya adalah melakukan create the subset untuk memilih daerah sesuai yang kita butuhkan. Karena data yang terekam 
tidak hanya meliputi wilayah Kota Padang, maka perlu dilakukan pemotongan citra sesuai dengan koordinat wilayah Kota Padang seperti pada Gambar 3.

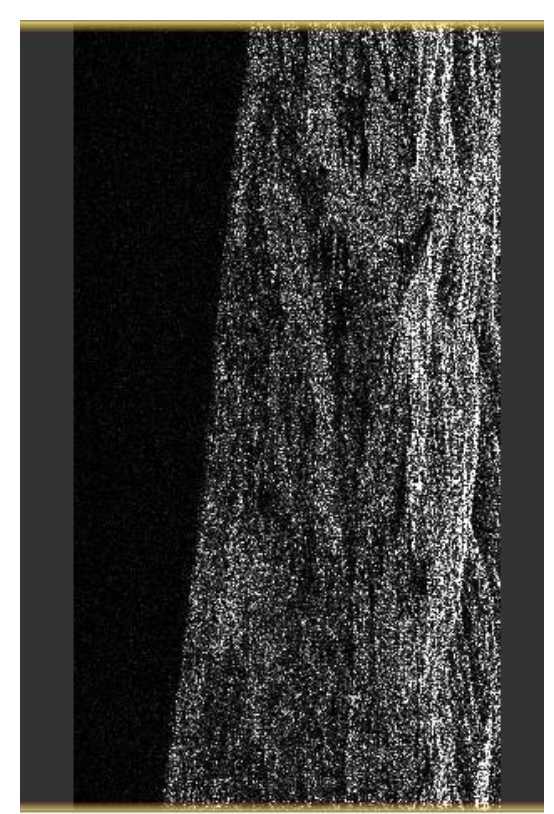

Gambar 2. Intensitas VH Band

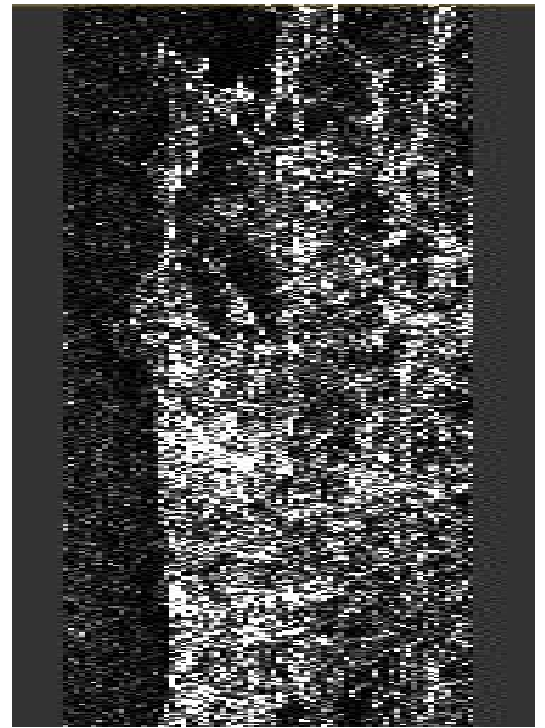

Gambar 3. Create the subset untuk Kota Padang

Tahapan selanjutnya adalah melakukan kalibrasi dimana proses kalibrasi pada pengolahan citra terdiri dari dua tahap yang pertama yaitu kalibrasi radiometrik. Proses kalibrasi ini dapat dilihat pada Gambar 4. Dan yang kedua adalah kalibrasi geometri yang dilakukan setelah hasil
E-ISSN : 2549-7464, P-ISSN : 1411-3724

pengolahan tahap polarimetri selesai dilakukan.

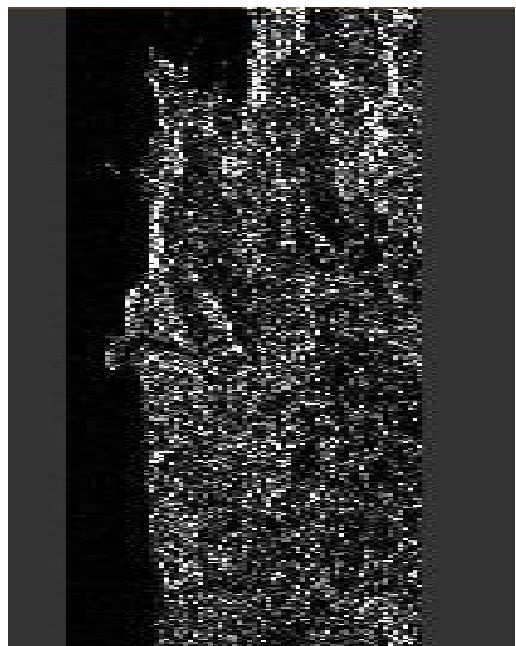

\section{Gambar 4. Kalibrasi Radiometri}

Kalibrasi

radiometri mempertimbangkan faktor gangguan atmosfer sebagai sumber kesalahan utama. Efek atmosfer menyebabkan nilai pantulan obyek di permukaan bumi yang terekam oleh sensor menjadi bukan merupakan nilai aslinya, tetapi menjadi lebih besar oleh karena adanya hamburan atau lebih kecil karena proses serapan.

Untuk tahap selanjutnya adalah tahap metode polarimetri yang terdiri dari beberapa proses diantaranya: matrix generation, speckle filtering dan decomposition. pada tahap Polarimetri matrix generation citra disusun oleh kovarian matrik yang diformulasikan dalam sebuah citra seperti yang terlihat pada Gambar 5.

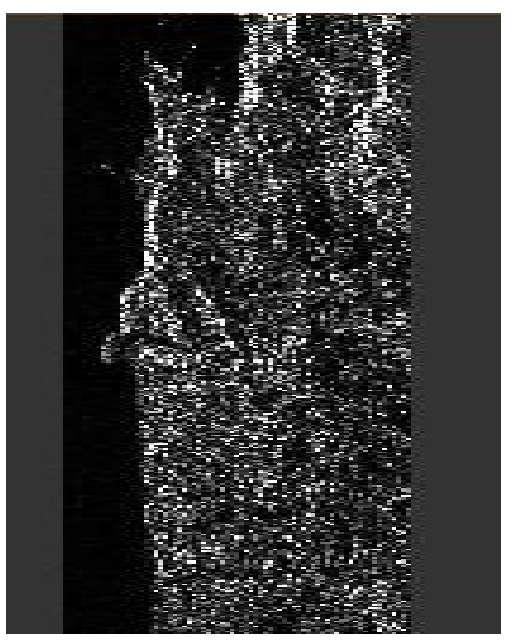




\section{Gambar 5. Matrix Generation}

Polarimetri matrix generation ini bisa menggunakan kovarians matrik C2,C3,C4 dan koherensi matrik T3 dan T4. Pada prosedur ini band yang dikonver adalah matrix T3 karena elemen-elemen yang terdapat pada T3 mempunyai interpretasi fisik yang lebih baik dan matrix ini lebih sering digunakan.

Selanjutnya adalah tahap polarimetri speckle filtering, Salah satu karakteristik citra SAR adalah timbulnya noise speckle, yang tampak sebagai tekstur bintik-bintik terang-gelap yang terdistribusi secara random dalam citra. Noise tersebut timbul akibat interferensi konstruktif dan destruktif diantara sinyal-sinyal hamburan balik dari berbagai obyek secara random dalam suatu areal tertentu yang disinarinya. Hasil pengolahan citra pada tahap ini dapat dilihat pada Gambar 6.

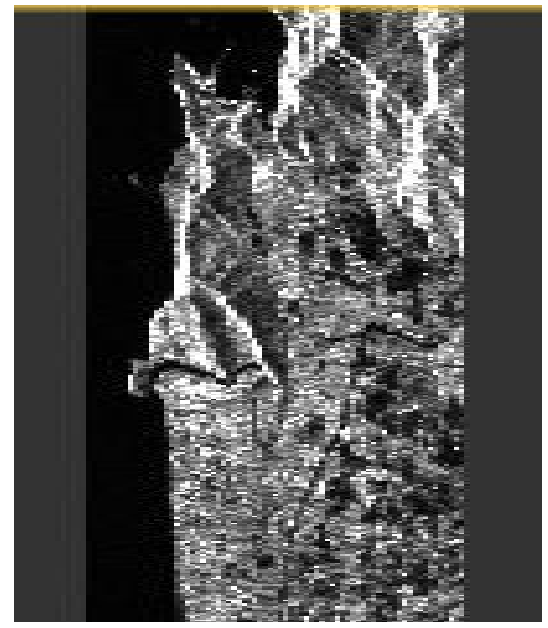

Gambar 6. Speckle Filtering

Tahap selanjutnya adalah polarimetric decomposition. Yang fungsinya untuk memisahkan kontribusi hamburan untuk setiap informasi. Ada banyak parameter yang tersedia pada bagian decomposition ini namun yang paling banyak digunakan adalah Yamaguchi Decomposition (Gambar 7). Yamaguchi decomposition dapat menghasilkan empat tipe scattering. Yamaguchi dkk pada tahun 2005, mengusulkan empat komponen model
E-ISSN : 2549-7464, P-ISSN : 1411-3724

scattering. Komponen keempat yang diperkenalkan adalah helix scattering. Istilah Helix scattering ini muncul untuk daerah-daerah yang heterogen (struktur buatan manusia) dimana menghilang (tidak terekam) ketika terjadi hamburan distribusi alami.

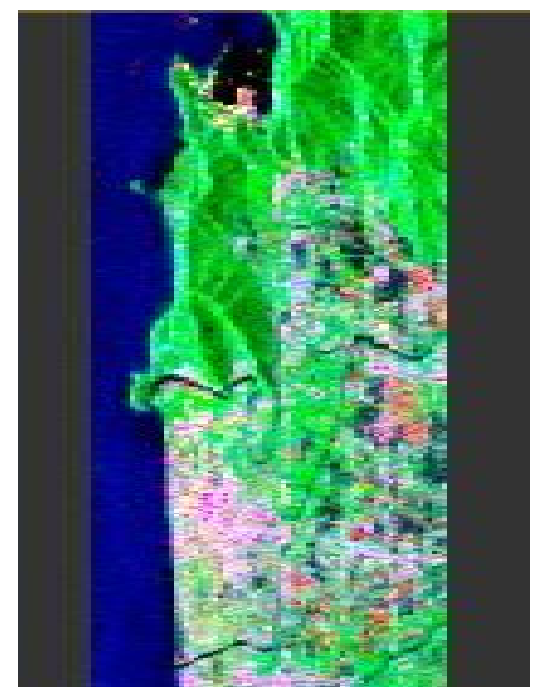

Gambar 7. Yamaguchi Decomposition

Setelah empat tipe scattering muncul berdasarkan aturan Yamaguchi decomposition, maka perlu dilakukan koreksi geometri yang ditujukan untuk memperbaiki nilai pergeseran bumi sehingga mudah untuk pengklasifikasian citra berdasarkan aturan Yamaguchi. Koreksi ini dimaksudkan untuk mengimbangi distorsi akibat variasi topografi dan kemiringan dari sensor satelit. Sehingga, dengan dilakukannya koreksi geometri ini dapat dilihat gambar geometrisnya dekat dengan keadaan realnya. Gambar 8 menampilkan hasil koreksi geometri terhadap citra. 


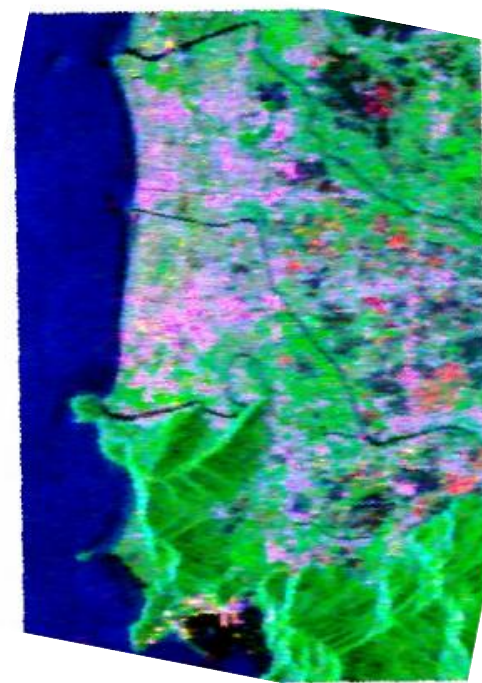

Gambar 8. Koreksi Geometri

\section{Pembahasan}

Berdasarkan hasil pengklasifikasian citra satelit ALOS PALSAR level 1.1 menggunakan metode polarimetri yang telah diolah yaitu matrix generation, speckle filtering, dan yamaguchi decomposition. Dapat diketahui bahwa pada pengolahan speckle filtering parameter yang digunakan adalah Refined lee filter yang dikembangkan berdasarkan model perkalian noise. Filter Refined Lee digunakan untuk menghaluskan noise (bintik) pada data yang memiliki intensitas yang berhubungan dengan citra serta mampu mempertahankan ketajaman gambar sekaligus menekan noise. Dalam pengolahan polarimetri Yamaguchi Decomposition peneliti dapat melihat empat model scattering yaitu surface scattering, volume scattering, helix scattering dan double bounce. Hasil pengolahan datanya di define dengan warna palsu merah,hijau dan biru (RGB) sehingga lebih mudah untuk membedakan dan menginterpretasikannya. Volume scatter merupakan klasifikasi citra yang umumnya menggambarkan tentang tumbuh-tumbuhan, hutan dan sejenisnya. Double bounce scatter merupakan klasifikasi citra yang menggambarkan tentang pemukiman, perkotaan, bangunan
E-ISSN : 2549-7464, P-ISSN : 1411-3724

dan sejenisnya. Surface scatter merupakan klasifikasi citra yang umumnya menggambarkan tentang perairan di permukaan bumi dan helix scatter sama halnya seperti double bounce namun helix akan lebih jelas mengidentifikasi pemukiman yang tertutupi tumbuhan. Pada hasil pengolahan tahap yamaguchi dekomposisi warna hijau untuk volume scattering, biru untuk surface scattering, merah atau pink untuk double bounce dan kuning untuk helix scattering. Dari hasil yang ditampilkan pada pengolahan citra dapat dilihat bahwa di kota Padang, pemukiman lebih padat untuk bagian daerah pinggir pantai.

\section{KESIMPULAN}

Proses pengolahan citra Alos Palsar level 1.1 dilakukan dengan menggunakan software SNAP dan metode polarimetri dengan langkah yaitu kalibrasi radiometrik, speckle filtering, matrix generation, dan yamaguchi decomposition serta koreksi geometrik. Berdasarkan hasil klasifikasi citra ALOS PALSAR level 1.1 menggunakan metode polarimetri, citra yang dihasilkan mampu mengklasifikasi objek dengan modifikasi penyederhanaan kelas. Kelas yang dihasilkan yaitu kelas pemukiman, vegetasi, dan badan air.

\section{DAFTAR PUSTAKA}

[1] Lillesand, T., M., dan R.W. Kiefer, 1993. Remote Senshing and Image, Terjemahan Pengindraan Jauh dan Interpretasi Citra. Gajah Mada University Press: Yogyakarta.

[2] Soenarmo, S.H. 2009. Penginderaan Jauh dan Pengenalan Sistem Informasi Geografis untuk Bidang Ilmu Kebumian, Penerbit ITB: Bandung.

[3] Prahasta, E. 2008. Remote Sensing: Praktis Pengindraan Jauh dan 
Pengolahan Citra Digital Dengan Perangkat Lunak Er Mapper. Informatika: Bandung.

[4] Danoedoro, P. 1996. Pengolahan Citra Digital: Teori dan Aplikasinya dalam Bidang Penginderaan Jauh. Fakultas Geografi Universitas Gadjah Mada: Yogyakarta.

[5] JAXA. 2013. Earth Observation Research Center, http:www.eorc.jaxa.jp /ALOS/en/ about/palsar.htm, diakses tanggal 8 Januari 2013.

[6] Djurdjani dan C.N. Kartini. 2004. Pengolahan Citra Digital. Jurusan Teknik Geodesi, Fakultas Teknik, Universitas Gadjah Mada: Yogyakarta.

[7] Wahyudi, C. 2010. Pengkajian Efektivitas Proses Speckle Filtering Pada Citra ALOS - Dual Polarization Menggunakan Beberapa Algoritma, http://chandra-w.blogspot.com/2010 /09/pengkajian-efektivitasprosesspeckle.html, diakses 3 Februari 2013.

[8] Yamaguchi.Y. 2007. Radar Polarimetry From Basics to Applications Tokyo. IEICE : Japan 